\title{
Karakter Habitus dan Viabilitas Biji Tanaman Biduri (Calotropis gigantea) Aksesi Lombok Tengah Bagian Selatan
}

\section{Character of Habitus and Seed Viability of Biduri (Calotropis gigantea) South Part of Central Lombok Accession}

\author{
Yuliani Ahmad ${ }^{1}$, M. Taufik Fauzi' ${ }^{2)}$, Bambang Budi Santoso ${ }^{3 *}$ \\ ${ }^{1)}$ Program Studi Agroekoteknologi Fakultas pertanian Universitas Mataram, Indonesia \\ 2) Jurusan Budidaya Pertanian, Fakultas Pertanian, Universitas Mataram, Indonesia \\ ${ }^{3 *}$ Kelompok Peneliti Bidang Ilmu Pengembangan Pertanian Lahan Kering, Fakultas Pertanian, Universitas \\ Mataram, Indonesia \\ *corresponding author, email: bambang.bs@unram.ac.id
}

Manuscript received:06-02-2020. Accepted: 03-07-2020:

\begin{abstract}
ABSTRAK
Penelitian bertujuan untuk mendeskripsikan karakter morfologi dan daya tumbuh tanaman biduri (Calotropis gigantea) aksesi yang tumbuh di kawasan wisata Lombok Tengah bagian Selatan (Kuta Mandalika, Tanjung Aan, dan Seger), dan telah dilakukan selama Februari-Agustus 2020. Metode yang digunakan adalah deskriptif observatif dengan teknik survei dan pengambilan sampel dengan purposive sampling berdasarkan populasi banyaknya biduri. Percobaan uji daya tumbuh menggunakan Rancangan Acak Lengkap di rumah kaca yang terdiri atas dua faktor yaitu jenis substrat dan aksesi, yang diulang tiga kali, sehingga terdapat 18 unit percobaan. Hasil penelitian menunjukkan bahwa tanaman biduri aksesi Kuta Mandalika memiliki keunggulan pada karakter jumlah buah per malai. Aksesi Tanjung Aan unggul pada karakter percabangan (cabang primer dan skunder), jumlah malai per pohon, jumlah bunga per malai, jumlah buah per pohon dan ukuran buah. Sedangkan aksesi Seger unggul pada karakter tinggi tanaman, ukuran biji dan berat 100 biji. Tidak ada perbedaan karakter pada viabilitas atau daya tumbuh biji dari ketiga aksesi. Hubungan kekerabatan terdekat terjadi pada aksesi Kuta Mandalika plot 2 sampel 2 dengan aksesi Kuta Mandalika plot 3 sampel 1 ditandai dengan nilai koefisien sebesar 1,00. Sedangkan hubungan kekerabatan terjauh terjadi pada aksesi Kuta Mandalika plot 1 sampel 1 dengan aksesi Tanjung Aan plot 2 sampel 2 dengan nilai koefisien sebesar 33,932 .
\end{abstract}

Kata kunci: biji; kekerabatan; percabangan; pertumbuhan; viabilitas

\footnotetext{
ABSTRACT

This study aims to describe the morphological character and seed growth potential of biduri (Calotropis gigantea) accession growing in the tourist area of South Central Lombok (Kuta Mandalika, Tanjung Aan, and Seger), and was carried out during February-August 2020. The method used was descriptive observative with survey techniques and sampling by purposive sampling based on the population of biduri. The seed growth experiment used a completely randomized design in a greenhouse consisting of two factors, namely the type of substrate and accession, which was repeated three times, so that there were 18 experimental units. The
} 
results shows that the Kuta Mandalika Biduri accession was showed superiority in the number of fruit characters per panicle. Tanjung Aan accessions excel in branching characters (primary and secondary branches), number of panicles per tree, number of flowers per panicle, number of fruits per tree and fruit size. Meanwhile, Seger accessions were superior in terms of plant height, seed size and weight of 100 seeds. There were no character differences in seed viability of the three accessions. The closest genetic-relationship occurs in the Kuta Mandalika accession of plot 2 sample 2 with the Kuta Mandalika accession of plot 3 sample 1 marked with a coefficient value of 1.00. Meanwhile, the furthest relationship was found in the Kuta Mandalika accession of plot 1 sample 1 with Tanjung Aan accession of plot 2 sample 2 marked with a coefficient value of 33.932 .

Keywords: branching; growth; genetic-relationship; seeds; viability

\section{PENDAHULUAN}

Tanaman biduri (Calotropis gigantae) merupakan tanaman belukar atau perdu atau semak liar yang dapat tumbuh mencapai tinggi 3 meter. Biduri banyak ditemukan pada lahan yang belum dimanfaatkan bahkan keberadaan biduri pada beberapa daerah dianggap sebagai gulma. Tanaman biduri merupakan tanaman asli Afrika tropis dan Asia Tenggara yang mudah ditemukan di Indonesia, Filipina, Kamboja, Malaysia, Srilanka, Thailand dan Cina (Crothers et al., 1998). Tanaman biduri umumnya ditemukan tumbuh pada zona panas dan kering, tempat terbuka yang mendapat penyinaran matahari penuh, lahan marginal, tanah tandus atau kering, dan tanah berpasir atau di sekitar pantai, bahkan dicela-cela bebatuan dimana tanaman lain tidak dapat tumbuh (Witono, 2008).

Menurut Sastroamidjojo (1967), tumbuhan biduri mengandung zat mudarrine (zat pahit), damar, alban, fluavil. Daun tumbuhan ini, sejak lama digunakan sebagai obat gatal dan kudis. Bunga nya dimanfaatkan secara tradisional sebagia obat asma dan sakit usus. Getahnya dimanfaatkan sebagai obat bisul dan obat sakit gigi. Selain sebagai bahan obat, biduri adalah tanaman penghasil serat yang tahan lama.

Hasil survey awal menunjukkan bahwa tanaman biduri banyak tumbuh liar pada kawasan Lombok Tengah khususnya di daerah pantai dimana kawasan tersebut merupakan kawasan tujuan wisata. Banyak dan mudahnya tanaman biduri ini tumbuh dan berkembang pada kawasan tersebut, disebabkan persyaratan tumbuh yakni iklimnya sangat mendukung. Oleh karena itu tanaman ini ditemkan banyak tumbuh secara liar di kawasan wisata yaitu daerah sekitar pesisir pantai Kuta Mandalika, pantai Aan, dan Seger yang memiliki kondisi wilayah dengan periode kering yang panjang. Kawasan tersebut termasuk lahan kering Lombok Tengah bagian Selatan.

Identifikasi awal dari suatu populasi tanaman yang tadinya liar namun memiliki potensi ekonomi jika dikembangkan sebagai tanaman budidaya, maka merupakan suatu kegiatan karakterisasi semua sifat yang dimiliki oleh sumber keragaman genetik tanaman atau aksesi yang menguntungkan tersebut. Identifikasi dilakukan untuk mencari dan mengenal ciri-ciri taksonomik individu yang beranekaragam dan memasukkannya ke dalam suatu takson (Mayr dan Ashlock 1999). Identifikasi berdasarkan karakter morfologi sangat berguna untuk mengetahui berbagai jenis dan keragaman tanaman biduri dan kemudian nantinya dapat digunakan sebagai dasar pengembangannya untuk mendapatkan jenis-jenis unggul ataupun dasar pengembangan aspek agronominya. Ketidaktersediaan informasi tentang keragaman tanaman biduri yang terdapat di Kawasan Wisata Lombok Tengah bagian Selatan, maka artikel ini memaparkan hasil penelitian terkait karakter morfologi dan hubungan kekerabatan tanaman biduri tersebut 


\section{BAHAN DAN METODE}

\section{Metode, waktu, dan bahan penelitian}

Metode yang digunakan dalam penelitian ini adalah metode Deskriptif Observatif dengan teknik survei dan pengambilan sampel dengan cara sengaja (purposive sampling) berdasarkan populasi tanaman biduri terbanyak tumbuh di kawasan. Penelitian ini dilaksanakan di Desa Kuta Mandalika, Kecamatan Sengkol, Kabupaten Lombok Tengah sejak bulan Februari sampai Agustus 2020. Populasi tanaman yang dipelajari adalah tegakan alami (liar) tanaman biduri (Calotropis gigantea).

\section{Pengumpulan Data}

Data primer yang dikumpulkan yaitu populasi seperti karakter morfologi (bunga, daun, batang, buah, dan biji), dan karakter fisiologi berupa uji viabilitas biji. Sedangkan data skunder yang dikumpulkan berupa data agronomi (ketinggian tempat, suhu dan curah hujan) yang didapatkan dari Badan Meteorologi, Klimatologi dan Geofisika (BMKG) Provinsi Nusa Tenggara Barat (NTB). Pengumpulan data sekunder ini bertujuan untuk mengetahui lingkungan tumbuh dan syarat tumbuh dari tanaman biduri.

\section{Pelaksanaan Observasi}

Penetapan lokasi penelitian. Dalam penentuan lokasi, ditetapkan 3 lokasi untuk tiap wilayah atau kawasan pantai bagian selatan yang memiliki kondisi iklim kering, curah hujan rendah, dan pada hamparan tampak padat tertumbuhi tanaman biduri, maka dipilih lokasi yaitu di sekitar pesisir pantai Kuta Mandalika, Tanjung Aan, dan Seger. Penentuan lokasi pertama didasarkan pada pintu masuk umum Kuta Mandalika. Setelah lokasi ditetapkan, pada masing-masing tempat dibuat 3 titik lokasi atau plot-plot per ukuran $10 \times 10 \mathrm{~m}^{2}$ (Mueller-Dombois dan Ellenberg, 1974). Letak atau penetapan plot dilakukan secara silang atau diagonal terhadap luasan kawasan. Pada setiap plot yang telah ditetapkan, dilakukan observasi terhadap: jumlah populasi tanaman biduri yang dijadikan sampel.

Penetapan sampel buah biduri. Penetapan titik sampel buah dipilih berdasarkan populasi terbanyak sebaran tanaman biduri di tiga kawasan pesisir Pantai Kuta Mandalika, Tanjung Aan, dan Seger yang dijadikan sampel penelitian. Tanaman yang dipilih adalah tanaman biduri dewasa, dari periode berbunga ditunggu hingga berbuah. Sampel buah terpilih kemudian dibungkus menggunakan kertas amplop, hingga total buah yang diambil sebanyak $1 \mathrm{~kg}$ untuk masing-masing plot.

Pengamatan. Pengamatan sampel berupa pengamatan vegetatif yaitu tinggi tanaman, warna batang, bentuk batang, jumlah cabang primer dan cabang sekunder, pola percabangan dan arah tumbuh batang, warna daun, bentuk daun, bentuk ujung daun dan panjang tangkai daun. Pengamatan generatif yaitu warna bunga, jumlah malai per pohon, jumlah bunga per malai, letak bunga, bentuk buah, jumlah buah per malai, jumlah buah per pohon, ukuran buah (panjang dan diameter), warna biji, bentuk biji, tekstur biji, ukuran biji (panjang dan lebar ) dan berat 100 biji serta pengamatan viabilitas biji biduri.

Pengamatan uji viabilitas biji. Pada uji viabilitas biji biduri menggunakan 2 substrat yaitu substrat tanah asli lokasi diperolehnya biduri dan subtrat pasir. Guna untuk mengetahui ada tidaknya perbedaan viabilitas (daya kecambah laju perkecambahan) dari aksesi terpilih. 
Metode yang digunakan dalam percobaan ini adalah metode eksperimental. Percobaan ini dilaksanakan dengan menggunakan Rancangan Acak Kelompok (RAK) Faktorial dengan 3 kali ulangan. Adapun perlakuan tediri dari dua faktor yaitu jenis substrat (S1= Pasir dan S2= Tanah) dan aksesi (A1= Aksesi Kuta Mandalika, A2= Tanjung Aan, dan A3= Seger). Setiap perlakuan diulang tiga kali, sehingga didapatkan delapan belas unit percobaan.

Menurut Sutopo (2004), rumus menghitung persentase perkecambahan (daya kecambah) dapat menggunakan rumus sebagai berikut:

$$
\text { Daya kecambah }=\frac{\text { jumlah biji yang berkecambah }}{\text { jumlah biji yang dikecambahkan }} \times 100 \%
$$

Kemudian menurut Sutopo (2004), cara menghitung laju perkecambahan dapat dirumuskan sebagai berikut:

$$
\text { Laju perkecambahan }=\frac{j u m l a h \text { biji yang berkecambah }}{\text { jumlah hari pengujian }}
$$

Data hasil pengamatan kemudian dideskripsikan dan juga dianalisis dengan menggunakan Analisis Cluster program SPSS 25.

\section{HASIL DAN PEMBAHASAN}

\section{Gambaran Umum Lokasi Penelitian}

Kecamatan Pujut merupakan kecamatan di Kabupaten Lombok Tengah dengan luas wilayah paling luas diantara 12 kecamatan yang ada yaitu sekitar 23.355 ha atau menempati sekitar 19,33 persen dari luas wilayah Kabupaten Lombok Tengah (BPS Kabupaten Lombok Tengah, 2016).

Kecamatan Pujut memiliki 2 (dua) musim, yaitu musim hujan dan musim kemarau. Menurut Badan Pusat Statistik (2015), Kecamatan Pujut termasuk daerah yang memiliki tingkat curah hujan terendah diantara kecamatan yang ada di Kabupaten Lombok tengah lainnya. Pada tahun 2015, hari hujan terbanyak terjadi pada bulan Januari diikuti bulan Februari, Maret dan April dengan hari hujan masing-masing 22 hari, 16 hari 10 hari dan 8 hari. Sementara hari hujan paling sedikit terjadi pada bulan November yang hanya 1 hari. Seperti halnya hari hujan demikian pula dengan curah hujan, dimana curah hujan terbanyak terjadi pada bulan Januari yang mencapai angka 416 mm, kemudian pada bulan Februari curah hujan mencapai 238 mm (BPS Kabupaten Lombok Tengah, 2016).

\section{Karakteristik Tanaman Biduri (Calotropis gigantea)}

Aksesi tanaman biduri yang diperoleh dari 3 wilayah di sekitar pesisir pantai Lombok Tengah bagian selatan mempunyai variasi yang berbeda-beda. Dapat dilihat pada Tabel 1. menunjukkan bahwa aksesi dari wilayah pesisir pantai Kuta Mandalika memiliki rata-rata tinggi tanaman yaitu 144,62 cm, wilayah Tanjung Aan memiliki rata-rata tinggi tanaman 145,35 cm dan wilayah Seger memiliki rata-rata tinggi tanaman yaitu $104,19 \mathrm{~cm}$. Adapun analisis tersebut dapat diketahui bahwa tanaman biduri yang berasal dari wilayah Tanjung Aan memiliki rata-rata tinggi tanaman yang lebih tinggi dibanding dengan wilayah lainnya. Hal ini sesuai dengan pendapat Dalirmartha (2003), bahwa tinggi tanaman biduri sekitar 0,5-3 m.

Warna batang tanaman biduri di kawasan Kuta Mandalika dari 15 aksesi yang diamati hanya satu sampel saja yang bewarna hijau dengan kode aksesi K35 dan sisanya didominasi oleh warna 
cokelat muda. Kawasan Tanjung Aan menunjukkan bahwa warna batang biduri didominasi oleh cokelat muda. Sedangkan untuk kawasan Seger, dari 15 aksesi terdapat 11 tanaman yang warna batangnya cokelat muda dan sisanya bewarna hijau dengan kode aksesi S1, S21, S31 dan S34. Menurut Tjitrosoepomo (2003) batang umumnya tidak berwarna hijau, kecuali tumbuhan yang umurnya pendek, misalnya rumput dan waktu batang masih muda.

Sifat bentuk batang, pola percabangan, dan arah tumbuh 45 aksesi yang diamati dari masingmasing wilayah tidak menunjukkan adanya keragaman. Bentuk batang biduri untuk wilayah Kuta Mandalika, Tanjung Aan dan Seger memiliki bentuk yang sama yaitu bulat silinder dengan pola percabangan yaitu simpodial. Hal ini sesuai dengan yang dikemukakan oleh Handayani (2003), bahwa tanaman biduri memiliki bentuk batang bulat silindris dengan percabangan simpodial (batang utama tidak tampak jelas). Sedangkan untuk arah tumbuh batang, rata-rata tanaman biduri untuk tiga kawasan tersebut memiliki arah tumbuh yang condong. Dari hasil identifikasi diduga bahwa tidak adanya keragaman terjadi karena tidak adanya pembeda genetik untuk sifat-sifat tersebut.

Cabang primer dan cabang sekunder aksesi Kuta Mandalika memiliki rata-rata cabang 3,6 dan 14,53 secara berurutan, di aksesi Tanjung Aan memiliki rata-rata 4,33 dan 13,67 dan aksesi untuk wilayah Seger memiliki rata-rata 3,27 dan 10,67. Menurut Holt (2000), produksi pada tanaman dipengaruhi oleh jumlah cabang yang terbentuk. Oleh karena itu besar kecilnya jumlah cabang mempengaruhi besar kecilnya hasil

Tabel 1. Keragaan tinggi tanaman Biduri aksesi Kuta Mandalika, Tanjung Aan, dan Seger

\begin{tabular}{|c|c|c|}
\hline Kode aksesi & Asal tanaman & Tingi tanaman $(\mathrm{cm})$ \\
\hline $\mathrm{K} 1$ & Kuta Mandalika & 143 \\
\hline $\mathrm{K} 2$ & Kuta Mandalika & 160 \\
\hline K3 & Kuta Mandalika & 174,5 \\
\hline K4 & Kuta Mandalika & 173 \\
\hline $\mathrm{K} 5$ & Kuta Mandalika & 170 \\
\hline $\mathrm{K} 21$ & Kuta Mandalika & 155,4 \\
\hline $\mathrm{K} 22$ & Kuta Mandalika & 147,5 \\
\hline $\mathrm{K} 23$ & Kuta Mandalika & 109,4 \\
\hline K24 & Kuta Mandalika & 120 \\
\hline $\mathrm{K} 25$ & Kuta Mandalika & 143 \\
\hline K31 & Kuta Mandalika & 102 \\
\hline K32 & Kuta Mandalika & 182,2 \\
\hline K33 & Kuta Mandalika & 139 \\
\hline K34 & Kuta Mandalika & 172 \\
\hline K35 & Kuta Mandalika & 78,3 \\
\hline Rata-rata & & 144,62 \\
\hline $\mathrm{T} 1$ & Tanjung Aan & 132,9 \\
\hline $\mathrm{T} 2$ & Tanjung Aan & 105,1 \\
\hline $\mathrm{T} 3$ & Tanjung Aan & 121,5 \\
\hline $\mathrm{T} 4$ & Tanjung Aan & 168 \\
\hline $\mathrm{T} 5$ & Tanjung Aan & 172 \\
\hline $\mathrm{T} 21$ & Tanjung Aan & 152 \\
\hline $\mathrm{T} 22$ & Tanjung Aan & 125,4 \\
\hline $\mathrm{T} 23$ & Tanjung Aan & 201 \\
\hline $\mathrm{T} 24$ & Tanjung Aan & 145 \\
\hline Kode aksesi & Asal tanaman & Tingi tanaman $(\mathrm{cm})$ \\
\hline $\mathrm{T} 25$ & Tanjung Aan & 139,3 \\
\hline T31 & Tanjung Aan & 115 \\
\hline T32 & Tanjung Aan & 170 \\
\hline
\end{tabular}




\begin{tabular}{ccc} 
T33 & Tanjung Aan & 117 \\
T34 & Tanjung Aan & 164 \\
Tanjung Aan & 152 \\
\hline Rata-rata & Tanjung Aan & 145,35 \\
\hline S1 & Seger & 95 \\
S2 & Seger & 120 \\
S3 & Seger & 115 \\
S4 & Seger & 107 \\
S5 & Seger & 170 \\
S21 & Seger & 75 \\
S22 & Seger & 46 \\
S23 & Seger & 139 \\
S24 & Seger & 78,2 \\
S25 & Seger & 61 \\
S31 & Seger & 47 \\
S32 & Seger & 132 \\
S33 & Seger & 162,7 \\
S34 & Seger & 95 \\
S35 & Seger & 120 \\
\hline Rata-rata & Seger & 104,19 \\
\hline
\end{tabular}

Tabel 2. Keragaan batang tanaman biduri

\begin{tabular}{|c|c|c|c|c|c|c|}
\hline \multirow{2}{*}{$\begin{array}{c}\text { Kode } \\
\text { Aksesi }\end{array}$} & \multicolumn{6}{|c|}{ Variabel Batang } \\
\hline & Warna & Bentuk & $\begin{array}{c}\text { Cabang Primer } \\
\text { (buah) }\end{array}$ & $\begin{array}{c}\text { Cabang Sekunder } \\
\text { (buah) }\end{array}$ & $\begin{array}{c}\text { Pola } \\
\text { Percabangan }\end{array}$ & $\begin{array}{c}\text { Arah } \\
\text { Tumbuh }\end{array}$ \\
\hline K1 & Cokelat muda & Bulat silinder & 2 & 14 & Simpodial & Condong \\
\hline $\mathrm{K} 2$ & Cokelat muda & Bulat silinder & 3 & 11 & Simpodial & Condong \\
\hline K3 & Cokelat muda & Bulat silinder & 2 & 9 & Simpodial & Condong \\
\hline K4 & Cokelat muda & Bulat silinder & 2 & 9 & Simpodial & Condong \\
\hline K5 & Cokelat muda & Bulat silinder & 4 & 20 & Simpodial & Condong \\
\hline $\mathrm{K} 21$ & Cokelat muda & Bulat silinder & 2 & 9 & Simpodial & Condong \\
\hline $\mathrm{K} 22$ & Cokelat muda & Bulat silinder & 5 & 19 & Simpodial & Condong \\
\hline $\mathrm{K} 23$ & Cokelat muda & Bulat silinder & 4 & 12 & Simpodial & Condong \\
\hline $\mathrm{K} 24$ & Cokelat muda & Bulat silinder & 2 & 9 & Simpodial & Condong \\
\hline $\mathrm{K} 25$ & Cokelat muda & Bulat silinder & 3 & 11 & Simpodial & Condong \\
\hline K31 & Cokelat muda & Bulat silinder & 5 & 18 & Simpodial & Condong \\
\hline K32 & Cokelat muda & Bulat silinder & 6 & 23 & Simpodial & Condong \\
\hline K33 & Cokelat muda & Bulat silinder & 3 & 17 & Simpodial & Condong \\
\hline K34 & Cokelat muda & Bulat silinder & 7 & 21 & Simpodial & Condong \\
\hline K35 & Hijau & Bulat silinder & 4 & 16 & Simpodial & Condong \\
\hline $\mathrm{T} 1$ & Cokelat muda & Bulat silinder & 5 & 14 & Simpodial & Condong \\
\hline $\mathrm{T} 2$ & Cokelat muda & Bulat silinder & 4 & 17 & Simpodial & Condong \\
\hline $\mathrm{T} 3$ & Cokelat muda & Bulat silinder & 2 & 9 & Simpodial & Condong \\
\hline $\mathrm{T} 4$ & Cokelat muda & Bulat silinder & 4 & 10 & Simpodial & Condong \\
\hline $\mathrm{T} 5$ & Cokelat muda & Bulat silinder & 8 & 32 & Simpodial & Condong \\
\hline $\mathrm{T} 21$ & Cokelat muda & Bulat silinder & 2 & 8 & Simpodial & Condong \\
\hline $\mathrm{T} 22$ & Cokelat muda & Bulat silinder & 2 & 7 & Simpodial & Condong \\
\hline $\mathrm{T} 23$ & Cokelat muda & Bulat silinder & 6 & 16 & Simpodial & Condong \\
\hline $\mathrm{T} 24$ & Cokelat muda & Bulat silinder & 2 & 8 & Simpodial & Condong \\
\hline $\mathrm{T} 25$ & Cokelat muda & Bulat silinder & 3 & 5 & Simpodial & Condong \\
\hline T31 & Cokelat muda & Bulat silinder & 4 & 13 & Simpodial & Condong \\
\hline T32 & Cokelat muda & Bulat silinder & 4 & 20 & Simpodial & Condong \\
\hline $\mathrm{T} 33$ & Cokelat muda & Bulat silinder & 7 & 11 & Simpodial & Condong \\
\hline T34 & Cokelat muda & Bulat silinder & 9 & 26 & Simpodial & Condong \\
\hline $\mathrm{T} 35$ & Cokelat muda & Bulat silinder & 3 & 9 & Simpodial & Condong \\
\hline $\mathrm{S} 1$ & Hijau & Bulat silinder & 4 & 11 & Simpodial & Condong \\
\hline
\end{tabular}




\begin{tabular}{ccccccc} 
S2 & Cokelat muda & Bulat silinder & 6 & 16 & Simpodial & Condong \\
S3 & Cokelat muda & Bulat silinder & 3 & 9 & Simpodial & Condong \\
S4 & Hijau & Bulat silinder & 3 & 10 & Simpodial & Condong \\
S5 & Cokelat muda & Bulat silinder & 2 & 7 & Simpodial & Condong \\
S21 & Hijau & Bulat silinder & 2 & 12 & Simpodial & Condong \\
S22 & Hijau & Bulat silinder & 2 & 7 & Simpodial & Condong \\
S23 & Cokelat muda & Bulat silinder & 2 & 8 & Simpodial & Condong \\
S24 & Cokelat muda & Bulat silinder & 2 & 11 & Simpodial & Condong \\
S25 & Cokelat muda & Bulat silinder & 2 & 8 & Simpodial & Condong \\
S31 & Hijau & Bulat silinder & 5 & 12 & Simpodial & Condong \\
S32 & Cokelat muda & Bulat silinder & 6 & 22 & Simpodial & Condong \\
S33 & Cokelat muda & Bulat silinder & 4 & 12 & Simpodial & Condong \\
S34 & Hijau & Bulat silinder & 4 & 10 & Simpodial & Condong \\
S35 & Cokelat muda & Bulat silinder & 2 & 5 & Simpodial & Condong \\
\hline
\end{tabular}

\section{Viabilitas Biji Biduri}

Pada Tabel 3. rata-rata daya kecambah biji aksesi Kuta Mandalika, Tanjung Aan dan Seger dengan perlakuan menggunakan pasir yaitu $81 \%, 71 \%$ dan $63 \%$ secara berurutan. Untuk perlakuan menggunakan tanah, rata-rata daya kecambahnya yaitu Kuta Mandalika 79\%, Tanjung Aan 69\% dan Seger 67\%. Rukmana dan Yuniarsih (2001) melaporkan bahwa suatu biji mempunyai daya kecambah yang baik apabila persentase perkecambahannya lebih dari $\geq 80 \%$. Terdapat hasil daya kecambah $\geq 80 \%$ yaitu pada aksesi Kuta Mandalika dengan perlakuan substrat pasir ditandai dengan nilai sebesar $81 \%$. Dari rata-rata daya kecambah biji di tiga aksesi tersebut dengan perlakuan pasir dan tanah dikategorikan daya kecambah biji yang rendah.

Tabel 3. Viabilitas biji biduri dengan perlakuan substrat pasir dan tanah

\begin{tabular}{lllc}
\hline \multicolumn{1}{c}{ Parameter } & Asal Aksesi & \multicolumn{1}{c}{ Perlakuan } & Nilai \\
\hline Daya kecambah (\%) & Kuta Mandalika & Pasir & 81 \\
& & Tanah alami & 79 \\
& Tanjung Aan & Pasir & 71 \\
& & Tanah alami & 69 \\
& \multirow{2}{*}{ Seger } & Pasir & 63 \\
& & Tanah alami & 67 \\
Laju perkecambahan (hari) & \multirow{2}{*}{ Kuta Mandalika } & Pasir & 2,88 \\
& \multirow{3}{*}{ Tanjung Aan } & Tanah alami & 2,83 \\
& & Pasir & 2,52 \\
& \multirow{2}{*}{ Seger } & Tanah alami & 2,67 \\
& & Pasir & 2,26 \\
& & Tanah alami & 2,40 \\
\hline LSD 5\% & & NS \\
\hline
\end{tabular}

Keterangan: NS = Non signifikan (berbeda tidak nyata)

Aksesi asal Kuta Mandalika memiliki laju perkecambahan untuk perlakuan pasir dan tanah alami sebesar 2,88\% dan 2,83\% secara berurutan, aksesi asal Tanjung Aan rata-rata laju perkecambahan yaitu 2,52\% dan 2,67\%, sementara untuk aksesi asal Seger yaitu sebesar 2,26\% dan $2,40 \%$. Hal ini berarti bahwa untuk mendapatkan biji yang serempak berkecambah untuk pasir dan tanah alami dibutuhkan waktu berturut-turut yaitu, aksesi asal Kuta Mandalika 8,65 hari dan 8,50 hari, Tanjung Aan berturut-turut yaitu 7,57 hari dan 8,01 hari sementara untuk aksesi asal Seger berturut-turut 6,78 hari dan 7,21 hari. 
Berdasarkan nilai jarak koefisien, semakin kecil nilai koefisien antar satu variabel dengan variabel lainnya, maka semakin dekat hubungan kekerabatan pada kedua variabel tersebut. Hal ini menandakan bahwa semakin dekat hubungan kekerabatan suatu sampel tanaman maka semakin sempit keragamannya. Dapat diketahui bahwa hubungan kekerabatan terdekat yaitu pada aksesi K22 (Kuta Mandalika plot 2 sampel 2) dan K31 (Kuta Mandalika plot 3 sampel 1) dengan nilai koefisien sebesar 1,00, sedangkan hubungan kekerabatan terjauh yaitu pada sampel K1 (Kuta Mandalika plot 1 sampel 1) dan T23 (Tanjung Aan plot 2 sampel 3) dengan nilai koefisien sebesar 33,932 (Tabel 4.4).

\section{Hubungan Kekerabatan Tanaman Biduri di Kawasan Wisata Lombok Tengah Bagian Selatan}

Pada Tabel 4. dapat diketahui bahwa perbedaan nilai koefisien hubungan kekerabatan terdekat dengan hubungan kekerabatan terjauh terlihat sangat besar. Meskipun terdapat pada lokasi yang sama, ternyata tidak dapat menjamin bahwa suatu tanaman memiliki tingkat hubungan kekerabatan yang dekat. Dapat dilihat pada sampel K1 (Kuta Mandalika plot 1 sampel 1) dan K2 (Kuta Mandalika plot 1 sampel 2) meskipun terdapat di lokasi dan plot yang sama yaitu desa Kuta Mandalika, memiliki hubungan kekerabatan yang cukup jauh dengan nilai koefisien 6,750.

Analisis kekerabatan digunakan untuk menentukan jauh dekatnya hubungan kekerabatan antara aksesi dengan menggunakan sifat morfologis dari suatu tanaman. Sifat morfologis dapat menggambarkan kekerabatan tingkat jenis. Jenis-jenis yang berkerabat dekat mempunyai banyak persamaan antara satu jenis dengan yang lainnya (Yuniarti, 2011). Rianto et.al. (2020) menyatakan, bahwa pengelompokkan ini didasarkan atas kesamaan karakter morfologi dan pemisahan terjadi didasarkan atas perbedaan karakter morfologi yang terdapat di antara aksesi tersebut.

Hasil analisis cluster dengan metode aglomeratif memperlihatkan bahwa biduri yang berasal dari desa yang sama belum tentu memiliki hubungan kekerabatan yang lebih dekat. Hubungan kekerabatan yang dekat dapat pula terjadi antar tanaman biduri yang berasal dari desa yang satu dengan desa lainnya. Gambaran hubungan kekerabatan biduri di kawasan wisata Lombok Tengah bagian selatan dapat dilihat pada Gambar 1 .

Tabel 4 Hubungan kekerabatan tanaman biduri aksesi Kuta Mandalika, Tanjung Aan dan Seger

\begin{tabular}{cccc}
\hline \multirow{2}{*}{ No } & \multicolumn{2}{c}{ Kombinasi Kelompok } & \multirow{2}{*}{ Koefisien } \\
\cline { 2 - 3 } & Kelompok 1 & Kelompok 2 & 1,000 \\
\hline 1 & K22 & K31 & 2,000 \\
2 & T1 & S2 & 2,000 \\
3 & K25 & T35 & 2,000 \\
4 & K34 & T34 & 2,000 \\
5 & K23 & K24 & 3,000 \\
6 & K33 & S32 & 3,000 \\
7 & T4 & T21 & 3,000 \\
8 & K1 & K23 & 4,000 \\
9 & T25 & S35 & 4,000 \\
10 & S24 & S34 & 4,000 \\
11 & K4 & S33 & 4,000 \\
12 & S4 & S23 & 4,000 \\
13 & T1 & T33 & 4,500 \\
14 & K32 & K33 & 4,667 \\
15 & K1 & K21 & 5,000 \\
16 & K3 & K4 & 5,333 \\
17 & K34 & T1 & 6,000 \\
18 & K35 & S1 & 6,000 \\
19 & K2 & T32 & 6,000 \\
20 & K25 & T24
\end{tabular}




\begin{tabular}{lccc}
21 & T3 & T4 & 6,500 \\
22 & K1 & K2 & 6,750 \\
23 & K32 & K34 & 6,800 \\
24 & S4 & S25 & 7,000 \\
25 & K3 & S24 & 7,333 \\
26 & K5 & K32 & 7,500 \\
27 & K1 & K22 & 7,833 \\
28 & S4 & S22 & 8,333 \\
29 & K3 & K25 & 8,400 \\
30 & K1 & K35 & 10,500 \\
31 & T22 & S4 & 11,250 \\
32 & K3 & S5 & 12,000 \\
33 & K3 & T25 & 12,778 \\
34 & T22 33 & 13,000 \\
35 & K1 & K5 & 13,722 \\
36 & K3 & S21 & 14,636 \\
37 & K1 & T5 & 14,895 \\
38 & K1 & K3 & 16,917 \\
39 & T2 & T3 & 17,333 \\
40 & T22 & S31 & 17,833 \\
41 & T2 & T31 & 19,500 \\
42 & K1 & T22 & 24,214 \\
43 & K1 & T2 & 32,128 \\
44 & K1 & T23 & 33,932 \\
\hline & Keterangan: K ( Kuta Mandalika), T (Tanjung Aan), dan S (Seger).
\end{tabular}

Aksesi Tanjung Aan memiliki tingkat kemiripan yang sangat jauh dibanding Aksesi Kuta Mandalika dan Seger, akan tetapi pada kluster 1, 2 dan 3 ditemukan juga sampel berasal dari Tanjung Aan. Pada kluster 1, sampel Tanjung Aan yaitu T32, T1, T33 dan T5, pada kluster 2 sampel Tanjung Aan yaitu T25, T35, dan T24, kemudian pada kluster ketiga sampel Tanjung Aan yaitu T22 dan T4. Ditemukannya sampel Tanjung Aan pada kluster yang didominasi oleh aksesi Kuta Mandalika dan 


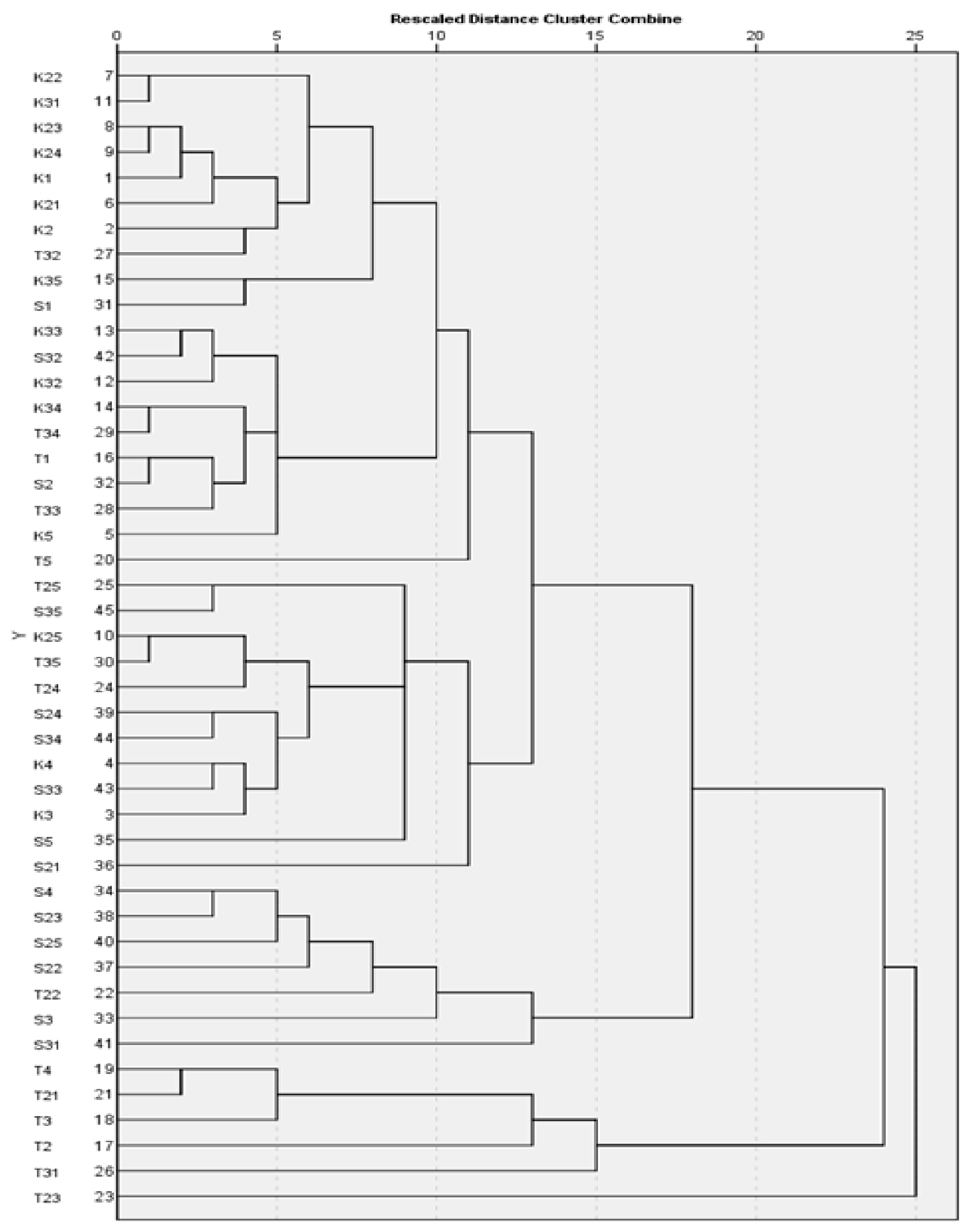

Gambar 1 Dendogram tanaman biduri antar aksesi Kuta Mandalika, Tanjung Aan dan Seger 
Seger menunjukkan bahwa adanya kemiripan karakter pada aksesi tersebut. Kemiripan pada aksesi tersebut dapat disebabkan oleh beberapa faktor diantaranya yaitu karena adanya variasi genetik oleh lingkungan, proses domestikasi tanaman atau campur tangan manusia dan hewan ternak sekitar tempat penelitian. Meskipun terdapat pada kondisi dan lokasi yang sama, baik ketinggian tempat ataupun iklim yang sama, namun tidak menjamin suatu tanaman memiliki kenampakan morfologi yang sama. Hal ini dikarenakan keragaman fenotip suatu tanaman dipengaruhi oleh faktor genetik dengan lingkungan tempat tumbuh tanaman tersebut. Meskipun ditanam pada suatu daerah yang sama tetapi jika lingkungan mikro ataupun asal bahan tanam awal berbeda maka akan dapat mempengaruhi pertumbuhan dan perkembangan tanaman yang diekspresikan melalui penampilan morfologinya. Dikatakan Irawan dan Purbayanti (2008), bahwa meskipun suatu kultivar berasal dari satu daerah namun bila lingkungan tumbuhnya berbeda akan mempengaruhi diversitas genetik dan juga genotipe yang berasal dari daerah yang sama tidak selalu berada dalam kelompok yang sama.

\section{KESIMPULAN}

Tanaman biduri dari seluruh aksesi yang diamati merupakan kelompok Calotropis gigantea dan memiliki perbedaan habitus yang relative kecil. Tanaman biduri aksesi Kuta Mandalika memiliki jumlah buah per malai tertinggi di antara ketiga aksesi. Aksesi Tanjung Aan memiliki jumlah cabang primer dan sekunder, warna bunga, jumlah malai per pohon dan jumlah bunga per malai, jumlah buah per pohon serta ukuran buah tertinggi di antara tiga aksesi tersebut. Sedangkan untuk aksesi Seger memiliki tinggi tanaman, ukuran biji dan berat 100 butir biji tertinggi di antara ketiga aksesi. Tinggi tanaman aksesi Seger adalah yang paling rendah. Viabilitas biji ketiga aksesi berbeda tidak nyata.

Berdasarkan data Squard Euclidean Distance, hubungan kekerabatan terdekat terjadi pada K22 (Kuta Mandalika plot 2 sampel 2) dengan K31 (Kuta Mandalika plot 3 sampel 1) dengan nilai koefisien sebesar 1,00. Sedangkan hubungan kekerabatan terjauh terjadi antara K1 (Kuta Mandalika plot 1) dengan T23 (Tanjung Aan plot 2 sampel 3) dengan nilai koefisien sebesar 33,932. Berdasarkan analisis dendogram aksesi dengan kode T23 memiliki hubungan kekerabatan terjauh dengan 44 kode aksesi lainnya. Aksesi kode T23 memiliki keragaman yang luas, berpontensi untuk dirakit menjadi kultivar-kultivar baru yang lebih unggul.

Domestikasi biduri liar menjadi tanaman budidaya sebaiknya menggunakan bahan tanaman dari aksesi Tanjung Aan. Keberhasilan kegiatan pemuliaan tanaman sangat bergantung kepada adanya variasi genetik yang luas..

\section{DAFTAR PUSTAKA}

Agra. 2008. Buku Pintar Tanaman Obat. Argromedia Pustaka. Jakarta.

Ahirwar, D., Ahirwar, B., Kharya, M. D. 2007. Influence of Calotropis procera Roots on Biochemistruy of Reproductive Organ of Ovariectomized Rats. Indian J. Pharm. Sci. 69: 459-461.

Badan Pusat Statistik Lombok Tengah. 2013. Kabupaten Lombok Tengah Dalam Angka 2013. Badan Pusat Statistik. Lombok Tengah. 
Badan Pusat Statistik Lombok Tengah. 2016. Kecamatan Pujut Dalam Angka 2016. Badan Pusat Statistik. Lombok Tengah.

Dalirmatha, S. 2003. Atlas Tumbuhan Obat Indonesia Jilid 3. Puspa Swara. Jakarta.

Handayani, L. 2003. Mengatasi Penyakit Anak dengan Ramuan Tradisional. Agro Media Pustaka. Jakarta.

Holt, J. G., Krieg, N. R., Sneath, P. H. A., Stanley, J.T., \& William, S.T. 2000. Bergeys Manual of Determinative Bacteriology, $9^{\text {th }}$ Edition. Lippincott. USA.

Irawan, B. dan Purbayanti, K. 2008. Karakterisasi dan Kekerabatan Kultivar Padi Lokal di Desa Rancakalong, Kecamatan Rancakalong, Kabupaten Sumedang. Seminar Nasional PTTI 21-23 Oktober 2008.

Mayr, E. and Ashlock P.D. 1999. Principles of Systematic Zoology. Second Edition. McGraw Hill International Edition. New York.

Mueller-Dombois, D. and Ellerberg, H. 1974. Aims and Method of Vegetation Ecology. Blackburn Press Caldwell. New Jersey.

Orwa, C., Mutua, A., Kindt, R., and Anthony, S. 2009. Moringa oleifera Lam. Moringaceae. A Tree Reference and Selection Guide Version. Agroforetree 4.0.

Rahmat, R. \& Yuniarsih. 2001. Aneka Olahan Ubi Kayu. Kanisius. Yogyakarta.

Ranjan, N., Kumar, S., and Kumari, C. 2017. Biologycal Morphology and EthanoPharmocologycal Imprortance of Calotropis Spesies- A Review. Int. J.Curr. App.Sci 6(4): 1640-1648.

Rianto, W.R., Sumarjan, dan B.B. Santoso. 2020. Karakter Tanaman Kelor (Moringa oleifera Lam.) Aksesi Kabupaten Lombok Utara. Jurnal Sains Teknologi \& Lingkungan. 6(1): 116-131. doi.org/10.29303/jstl.v6i1.158

Suryadi. 2003. Karakterisasi dan Deskripsi Plasma Nutfah Kacang Panjang. http://indoplasma.or.id/publikasi/buletin_pn 91 7-11.

Witono, Y. 2013. Enzim Biduri: Agen Aktif Potensial untuk Proses Pangan Pustaka Radja. http://scholar.google.co.id/scholar?hl=id\&as_sdt=02C5 \&q=yuli+w+bu $\mathrm{ku}+$ enzim+biduri+agen+aktif+potensial\&oq=yuli+w\#d=gs_gabs\&u=\%23p\%3D1AxFN iQZsJMJ.

Yuniarti. 2011. Inventarisasi dan Karakterisasi Morfologis Tanaman Durian (Durio zibethinus Murr.) di Kabupaten Tanah Datar. Jurnal Plasma Nutfah. 3(2): 23-31. 